\title{
The Value Relevance of Accounting Information: Evidence from Nigeria
}

\author{
Okuns Omokhoje Omokhudu ${ }^{1}(\mathrm{PhD}) \&$ Peter Okoeguale $\operatorname{Ibadin}^{1}(\mathrm{PhD})$ \\ ${ }^{1}$ Department of Accounting, Faculty of Management Sciences, University of Benin, Benin City, Nigeria \\ Correspondence: Peter okoeguale Ibadin (PhD), Department of Accounting, Faculty of Management Sciences, \\ University of Benin, Benin City, Nigeria. E-mail: prinadmultilink@yahoo.com
}

Received: May 19, 2015

Accepted: June 15, 2015

Online Published: June 24, 2015

doi:10.5430/afr.v4n3p20

URL: http://dx.doi.org/10.5430/afr.v4n3p20

\begin{abstract}
Value relevance of accounting information addresses the degree to which accounting information summarizes the information that is impounded in share prices. Therefore, the purpose of this paper is to contribute to the empirical literature on value relevance by examining the extent to which accounting information is associated with firm value, from an emerging market context. The paper uses the basic Ohlson (1995) model and the modification of the model that includes cash flow from operation, and dividends, to ascertain the value relevance of accounting information in Nigeria. The paper accommodates the documented relative inefficiency of the market by using stock price at three months and six months after year end as dependent variable. The study employs a pooled and panel data in the regression of share price and returns on accounting numbers. The ordinary least square (OLS) estimation and dynamic model estimation, with the Random and Fixed effects variants were used in the regression. We find that earnings, cash flow and dividends were statistically significantly associated with firm value but book value was related but not statistically significant. Based on these findings, it is suggested that the focus of investors should be on earnings, dividends and cash flows while less emphasis be placed on book values. Besides, the accounting information for investment purposes should be communicated to the investing public; and such information should be of high quality to avoid sub-optimal investment decisions by investors, with negative consequences for the overall economy
\end{abstract}

Keywords: Value Relevance, Share price, Accounting Information, Nigeria Stock Exchange

\section{Introduction}

The primary thrust of this study is to investigate the relevance of accounting information to equity valuation of Nigerian Listed companies, in the secondary capital market of Nigeria. The value relevance of such accounting measures, as earnings and book value of assets, could be evaluated by the market's response to accounting information provided by reporting companies in any period. Share prices reflect the aggregate behavior of investors. The market response to published accounting information is measured by the coefficient in a regression model using share price or stock return as the dependent variable and accounting measures, such as earnings, book value and cash flow as the independent variables.

Financial reports have a primary objective of providing information for investment decision making. Consequent upon this, the usefulness of information contained in financial reports depends upon their usefulness for investment decision making. From investors' perspective, information is relevant if it contributes to the equity investment decisions of the investor. Useful accounting information must possess the primary attributes of relevance and reliability. Relevant accounting information must possess the capacity to influence the decision of the investor.

In the literature, relevance of accounting information is ascertained by the value relevance of accounting information. The empirical operationalisation of relevance of accounting information in the extant accounting literature is referred to as value relevance. Barth, Beaver and Landsman (2001) summarize value relevance as the "... ability of financial statement information to capture or summarize information that affects share values..." Holthausen and Watts (2001) see value relevance as the empirical relation between stock market values (or changes in values) and particular accounting numbers for the purpose of assessing or providing a basis for assessing the numbers used or proposed use in accounting standard.

Some studies on value relevance have appeared in the developed countries. Nigeria, being the largest emerging country in the Sub-Saharan Africa, has had its owns share of the value relevance literature: Studies have been conducted in Nigeria to ascertain the value relevance of accounting information (Adaramola \& Oyerinde, 2014, Abiodun, 2012, Oyerinde, 2009, Omokhudu \& Otakefe, 2004).But questions remain as to whether the relevance of accounting 
information has increased or decreased over time. Studies in other emerging markets find that the explanatory power of earnings of stock return is very limited and consistent with the US prior studies (Zhao \& Zang 1999, Sami \& Haiyan 2004).

In the last two decades, the accounting literature has focused increasingly on examining the value relevance of accounting information. Ibadin (2015) and Collins, Maydew and Weiss (1997) assert that the common belief that traditional financial statements have lost their relevance, is adduced to the transition from industrialized economy to high-tech, service-oriented economy. However, there are contradictory inferences on the direction of change in relevance and its source. Collins, Maydew, and Weiss (1997), Francis \& Schipper (1999) demonstrate an increasing trend in value relevance. Lev and Zarowin (1999), Core, Guay and Buskirk (2003) find evidence of declining value relevance of accounting information. This leaves the question of declining value relevance, an empirical matter, demanding new empirical evidence and insights, from a setting different from previous studies.

This study is therefore motivated by the hunger to address these gaps; and further motivated by the fact that the relevance of accounting information to equity valuation in Nigeria has not been robustly addressed in empirical literature. Nigeria is an emerging economy, and one that occupies a principal place in the West African sub region. It is the largest economy in Sub-Saharan Africa, with a large market. It also has a functioning and active financial system, with well established professional accounting community.

The principal objective of this study in the context of the problem identified in the foregoing is to ascertain if accounting information of listed firms in the Nigerian Stock Exchange is relevant for investment decision making. This study in the context of the documented inefficiency of the Nigerian Stock Exchange market (Osamwonyi and Anikamdu, 2002; Osaze, 2007) employs a methodology that addresses the problem of the inefficiency of the Market. In order to achieve this, the dependent variable of firm value indicated by stock price is taken at three months and six months after year end. This is to allow for accounting information to be reflected in investor decision making, hence impounded in share prices. The study covers a period of twenty years, and utilizes dynamic models of Random and Fixed effects models so to address the problem of the heterogeneity of sample data.

\section{Review of Literature and Hypotheses Development}

The primary purpose of financial reports is to enable investors make investment decisions. In this nexus, accounting information is crucial, as the extant literature has demonstrated that accounting information is related to value, and by extension, relevance (Ball \& Brown, 1968; Beaver, 1968; Lee, 1989; Brimble \& Hodgson, 2007). Biesland (2008) defines value relevance as the ability of financial statement information to capture and summarize information that determines firm value. It is the extent to which accounting information summarizes the information that is impounded in share values. The value relevance literature is both expansive and diverse; the various studies of value relevance differ on several platforms, ranging from perspectives on accounting, market assumptions underlying previous studies to research methods employed in the studies.

Ayed and Abaoub (2006) examine the value relevance of accounting earnings and components in the Tunisia Stock Exchange . Employing a sample of 262 firm-years, over the period 1997 to 2004, in which the new accounting system of companies was introduced, but before the introduction of the standard of consolidation in 2005, they tested three hypotheses. First, that operating earnings before taxes are more value relevant than bottom line earnings in explaining returns; second, that earnings components are more value relevant in explaining returns, and, third, that cash flow from operations is not value relevant and have no incremental information content beyond earnings. Ayed and Abaoub (2006) present empirical evidence that operating income before taxes, special items and income taxes are value relevant for firm valuation and that cash flow from operation and accruals are not value relevant.

Futhermore, $\mathrm{Ng}$, Gul and Mensah (2007) examine the effect on value relevance of accounting earnings after the coming of Sarbanes-Oxley Act in 2002 and managerial entrenchment characteristics. Using a sample of firms included in IRRC takeover measure data base, and merging with data in Compustat CRSP, they derive for 13,986 firm-years. They find that the value relevance of earnings is significantly different for three sub-periods in which the sample of observations was partitioned. Employing the existence of anti-managerial entrenchment mechanism, as a measure of good corporate governance, they observe that these measures have a positive impact on value relevance of accounting earnings in the period of Enron Scandal. Increases in value relevance of accounting earnings was only obtained in those firms that engaged in income-decreasing earnings management during the years prior to the Enron scandal.

In Ben Naceur, and Nachi's (2007) study on accounting reforms and value relevance, the researchers examine the impact of the accounting reforms on the value relevance of financial information in the Tunisian Stock Exchange (TSE). They examine whether market's evaluation of earnings and book values improved the investors' decision after 
the implementation of accounting returns. Using a sample of firms trading in the TSE from the period 1992-2001, they examine the relationship between earnings, book value and cash flow with stock prices, before and after accounting reforms. The documented evidence from the examination reveals that earnings, cash flows and book values are significantly and positively related to share prices. It is also shown that value relevance of accounting information has significantly improved after the 1997 accounting reforms; and that the factors of firm size and branch of activity have not improved the value relevance of accounting information in TSE following the accounting reforms.

Pourheydari, Aflatooni and Nikbakat (2008) compare the combined value relevance of dividends and book value with the value relevance of earnings and book value and their relationship with market value of shares in Tehran Stock Exchange from 1996 to 2004. Their results show a positive relationship between dividends, book value and earnings with stock market value. They also find that dividends have information content. The information content of dividends, combination of book values and earnings and combination of book values and dividends are approximately equal. The value relevance of all variables however was found to decline over time.

Habib and Elhamaney (2009) adopt the Pope and Wang's (2004) residual income specification instead of the commonly used Ohlson model to asceratain the value relevance of accounting information in Egyptian equity market. The study was drawn up from financial statements of 88 firms as of the year end 2005. Their result shows a positive correlation between cash flow and equity market values in Egypt. They further state that when the model estimation is based on earnings components of accounting accruals, the valuation weight of abnormal earnings goes up by about a factor of three in order to make up for the negative correlation between accounting accruals and equity market values. This supports the study major findings that accounting accruals are value relevant.Kirkulak and Balsari (2009) analyse the effect of inflation adjusted data on explaining the market value of equity and stock returns in Turkey. They find that both historical cost-based book value and earnings information and inflation adjusted information are value relevant and they complement each other.

Oyerinde (2009) investigates the value relevance of accounting data in the Nigerian Stock Market, with the objective of establishing the relationship between accounting numbers and share prices in the Nigerian Stock Market. The study measures value relevance by the correlation coefficient between stock prices and some accounting numbers. The study shows that accounting information has the ability to capture information that affects equity values and that there is relationship between accounting numbers and share prices in Nigerian Stock Market. This study however shows a number of serious limitations: the time scope for this study was narrow, such that conclusions from this study could not be compared to studies done in more matured markets. It also did not take into cognizance the factor of scale as well as the effects of heteroscedasticity.

Pereia and Thrikawala (2010) analyse the published financial statements of commercial banks listed in the Colombo Stock Exchange over the period 2005 -2009. Their result shows that the earnings per share and earnings yield and return on equity have not declined in value relevance. They argue that investors react accordingly to the aggregate of accounting information which is published in the financial statement and without confidence in accounting numbers as a whole investors will not take their investment decisions. this imports generally that investors do not focus on short term capital gains or irrational or unusual events.

Keener (2011) examines the differences in the value relevance of earnings and book values across industries. He presents evidence that joint value relevance of earnings and book values had not declined, even though the incremental value relevance of earnings increased; while the vale relevance of the book values was unchanged for the period. Using a sample of firms quoted in the Athens Stock Exchange over the period 1996-2008, Glezakos, Mylonakis and Kafuoros (2012) examine the impact of earnings and book values on share prices, they find that the explanatory power of earnings and book values in share prices had increased over time. They also provide evidence that in the last years earnings played an increasingly declining role in the determination of share prices relative to book values.

Halonen, Parlovic and Pearson (2012) employ a simplified Ohlson's (1995) model, investigate value relevance of financial reporting in Sweden after the introduction of the International Financial Reporting Standard in 2005. They find that value relevance of book values had increased but the value relevance of earnings had decreased over the period. Olga and Veltri (2012) investigate the incremental value relevance of aggregate comprehensive income compared to net income, surveying empirical literature on value relevance tests, value relevance approach and other comprehensive income measure. They find that majority of studies did not support the incremental value relevance of other income over net income.Melissa (2013) addresses the relationship between share price and bottom line accounting information as dividends, earnings and book value in the Nairobi Stock Exchange. The study shows that earnings and book values are significantly associated with share values, though book value was found to be least significant of the three variables. Ayzer and Cema (2013) examine the value relevance of financial statement 
information in Turkish Stock Markets during the period 1997-2011, using the Ohlson (1995) mode. Their result shows that combined book values and earnings are significantly value relevant in explaining stock prices in the Turkish Stock Markets. Book values and earnings were individually significantly value relevant, with book values having higher explanatory power than earnings.

Sibil (2013) investigates the value relevance of accounting information in pre and post financial periods of IFRS adoption for Turkish listed firms. Market value per share is related to book value per share and earnings per share by using the Ohlson model (1995). Overall book value is value relevant in determining market value or stock prices. The result shows that value relevance of accounting information has improved in the post IFRS period considering book values while no improvement has been observed in value relevance of earnings. Adaramola and Oyerinde (2014) examine the trend in value relevance of accounting information, using a sample of sixty six listed companies in the Nigerian Stock Exchange. The study found that value relevance of accounting information did not follow any trend, but it was lower in the period of military dictatorship and global economic crisis. Using accounting ratios, Vijltha and Nimalathasan (2014) study the value relevance of accounting information in the Colombo Stock Exchange. The study find significant association of Earnings Per Share, Net Asset Value Per Share and Return On Equity, with share prices of listed firms on the Exchange.

In the context of the foregoing review of literature it is hypothesized that:

$H_{1:}$ Accounting information of firms listed in NSE is not value relevant.

$H_{2:}$ Earnings are not statistically associated with share prices for listed firms in NSE

$H_{3:}$ Book values are not statistically associated with share prices for listed firms in NSE

$H_{4:}$ Cash flow from operation is not significantly associated with share prices in NSE

$H_{5:}$ Dividend is not significantly related to share prices for listed firms in NSE.

\section{Methodology and Data}

The population of this study comprises all companies listed in the Nigerian Stock Exchange (NSE) during the twenty year period 1994-2013. To select the sample, the following restrictions were imposed: sampled company must be listed each year over the period 1994 to 2013; the financial year end of the sample companies must be December, 31; the firm has published its complete financial statements for the twenty years period from 1994 to 2013; to ensure some homogeneity of information, firms in banking and insurance sectors are excluded and the shares of sampled companies must be actively traded in the period under consideration.

In the light of the above consideration, a random sample of forty-seven firms was obtained, giving a sample of 940 firm-years. The data used in the analysis consist of 47 firms quoted on the Nigerian Stock Exchange from 1994 to 2013, a period of twenty years. The sample covers all industries excluding firms in the financial industry. The accounting data were collected primarily from the financial statements of the sample firms, Nigerian Stock Exchange Fact books and Nigeria Stock Exchange daily price quotations. Share price data 3 and 6 months after year end was collected daily from share price quotations. Accounting data extracted from financial statements were supplemented by NSE fact books.

\subsection{Data analysis and Model specification}

\subsubsection{Data analysis}

In keeping with previous studies on value relevance of accounting information, this study employs regression analysis to test the hypotheses raised. Value relevance is determined by the estimated regression coefficients of accounting variables included in the model and the (R-Squared- $\left.\mathrm{R}^{2}\right)$. The analysis is based on the Ohlson (1995) valuation model which states that the firm value is a linear function of book values of owners' equity and earnings. Following Dechow (1994) and Ortega (2006), this study includes cash flow, as it is suspected that cash flow may provide additional information about firms' financial situations not captured in earnings and book value in the context of the Nigerian economy. The basic Ohlson's (1995) model is also modified to accommodate dividends following Brief's (2000) suggestion.

A Pool and Panel ordinary least square estimation and regression were used; the dynamic models of Random Effects Model (REM) and Fixed Effects estimation model (FEM) variants, are employed to accommodate the heterogeneity of the data. as established by the Fisher test. The panel model estimation is utilized as it addresses the problem of data points and generates additional degrees of freedom. The Hausman test is employed to determine which of the effects models is more applicable to the sample data. 


\subsubsection{Models Specification}

The basic model derived within the Ohlson (1995) framework, stated as

$$
\mathrm{P}_{\mathrm{jt}}=\alpha_{0}+\alpha_{1} \mathrm{E}_{\mathrm{jt}}+\alpha_{2} \mathrm{BV}_{\mathrm{jt}}+\varepsilon_{\mathrm{jt}}
$$

We modify the basic model to accommodate cash flow, thus the model is stated as

$\mathrm{P}_{\mathrm{jt}}=\alpha_{0}+\alpha_{1} \mathrm{E}_{\mathrm{jt}}+\alpha_{2} \mathrm{BV}_{\mathrm{jt}}+\alpha_{3} \mathrm{CF}_{\mathrm{jt}}+\varepsilon_{\mathrm{jt}}$

In order to accommodate the effect of dividend the Ohlson model is modified as

$$
\mathrm{P}_{\mathrm{jt}}=\alpha_{0}+\alpha_{1} \mathrm{E}_{\mathrm{jt}}+\alpha_{2} \mathrm{BV}_{\mathrm{jt}}+\alpha_{3} \mathrm{DIV}_{\mathrm{jt}}+\varepsilon_{\mathrm{jt}}
$$

\section{Results}

The descriptive and inferential statistics and laid down in the respective tables below.

Table 1. Descriptive Statistics for the sampled companies

\begin{tabular}{lllllll} 
& Mean & Median & Maximum & Minimum & Std. Dev. & Observations \\
\hline BVPS & 5.020503 & 3.04255 & 192.457 & -91.27766 & 10.13671 & 940 \\
CFOPS & 1.696384 & 0.529118 & 37.28344 & -9.902525 & 4.18497 & 940 \\
DPS & 62.68745 & 12.5 & 3600 & -16.8 & 179.6574 & 940 \\
EPS & 1.038793 & 0.40598 & 33.82083 & -94.60538 & 4.162596 & 940 \\
SHP1 & 16.55206 & 3.96 & 300.98 & 0.5 & 34.70247 & 940 \\
SHP2 & 17.41489 & 3.98 & 360 & 0.5 & 37.45007 & 940
\end{tabular}

Table 1 presents the descriptive statistics for the sample over a period of 20 years from 1994 to 2013. The earnings per share (EPS) over the period with the average earning per share at 1.21 and standard deviation of 2.81. Share price at 3 months after year end (SHP1) has mean and standard deviation of N16.6 and N34.7 respectively. Share price 6 months after year end (SHP2) has a mean and standard deviation of N17.4 and N37.4 respectively. The mean of DPS is 63.6kobo per share. Standard deviation of this variable is $181.5 \mathrm{k}$. With respect to cash flow per share (CFOPS), the maximum value is $\mathrm{N} 37.28$ and the minimum value is $\mathrm{N} 9.90$. The average stood at N1.72, with standard deviation at N4.13. Book value per share (BVPS) has a mean value in period of N5.22 and a standard deviation of N9.82. .

\subsection{Discussion of Results}

The regression analysis is undertaken with the dependent variable taken at 3 months and 6 months after year end, in order to accommodate the inefficiency of the market. As opined by Dung(2010), using prices some time after year end has the advantage of impounding more fully the accounting information at year end. The inefficiency of the market demands the passage of time to afford the resolution of the inefficiency of the market in accommodating accounting information released after year end.

The regression analysis is carried out under four different techniques, Pooled OLS, Panel OLS, Random Effect Model and Fixed Effect Model. 
Table 2. Regression results for model 1

\begin{tabular}{|c|c|c|c|c|c|c|c|c|}
\hline & \multicolumn{8}{|c|}{$P_{\mathrm{jt}}=\alpha_{0}+\alpha_{1} \mathrm{EPS}_{\mathrm{jt}}+\alpha 2 \mathrm{BVPSjt}+\varepsilon_{\mathrm{jt}}$} \\
\hline & \multicolumn{4}{|c|}{ Dependent Variable SHP1 } & \multicolumn{4}{|c|}{ Dependent Variable SHP2 } \\
\hline & $\begin{array}{l}\text { POOLED } \\
\text { OLS }\end{array}$ & $\begin{array}{l}\text { PANEL } \\
\text { OLS }\end{array}$ & REM & FEM & $\begin{array}{l}\text { POOLED } \\
\text { OLS }\end{array}$ & $\begin{array}{l}\text { PANEL } \\
\text { OLS }\end{array}$ & REM & FEM \\
\hline \multirow[t]{2}{*}{ Intercept } & 16.14 & 27.59 & 14.08 & $14.47 * *$ & 13.53 & 50.26 & 14.52 & 14.47 \\
\hline & -5.21 & & $(6.520$ & -14.62 & -5.44 & -3.24 & -2.04 & -14.62 \\
\hline \multirow[t]{2}{*}{ EPS } & 0.76 & 0.38 & $1.69 * *$ & $1.42 * *$ & 3.11 & $0.41 * *$ & $1.92 * *$ & $1.43 * *$ \\
\hline & -1.61 & -2.39 & -6.61 & -5.47 & -0.09 & -2.72 & -2.86 & -5.47 \\
\hline \multirow[t]{2}{*}{$B V P S$} & -0.07 & -0.17 & $0.14 * *$ & 0.12 & 0.11 & $-0.26^{* *}$ & 0.14 & 0.12 \\
\hline & $(-0.41)$ & $(-2.68)$ & -1.38 & -1.12 & -0.86 & $(-4.24)$ & -0.63 & -1.12 \\
\hline$R^{2}$ & 56.4 & 65.9 & 6.5 & 43.8 & 18.2 & 72.3 & 7.5 & 43.8 \\
\hline $\operatorname{Adj} R^{2}$ & 56.2 & 65.8 & 6.3 & 40.8 & 17.9 & 72.1 & 7.3 & 40.1 \\
\hline$F$-stat & $402.4^{* *}$ & $573.8^{* *}$ & $32.64 * *$ & $14.48^{* *}$ & $69.2 * *$ & $765.86^{* *}$ & $37.6^{* *}$ & $14.5^{* *}$ \\
\hline $\operatorname{Prob}(F-$ stat $)$ & 0 & 0 & 0 & 0 & 0 & 0 & 0 & 0 \\
\hline \multicolumn{6}{|l|}{ Hausman } & & & $2(2)$ \\
\hline (P-values) & & & $45.01 * *$ & & & & & $45.01 * *$ \\
\hline
\end{tabular}

The above table shows earnings having a positive relationship with the dependent variable share price at 3 months and 6 months after year end. Using Pooled, Panel, Random effect and Fixed effect model (t-statistics=1.61,2.39, 6.61 and 5.47) and (P-values $=0.11,0.02,0.00$ and 0.00$)$ at Shp1. The result shows strong positive relationship of earnings with share price, with pool estimation not significant. At Shp2, using Pooled and Panel ( Random effects and Fixed effects models) with t-statistics $=0.09,2.72,2.86$ and 5.47 and (P-values $=0.09,0.006,0.004$ and 0.00 , we reject the null hypothesis and conclude that earnings are value relevant for firms listed on the NSE. This result is consistent with Oyerinde (2011)

The result from book values, using the pool and panel estimation are inconsistent with dynamic models of Random Effecst and Fixed Effects models. Using the pool and panel with t-statistics = 1.61 and 2.39) and P-values $=0.11$ and 0.02, at shp1. At shp2, using the pool and panel least square estimation, given t-statistics 0.86 and -4.24 and $\mathrm{P}$-values $=$ 0.39 and 0.00 , result shows a negative but insignificant relationship between book values and share price. The Random effect and Fixed effect model have t-statistics $=1.38$ and 1.12 and P-values $=0.17$ and 0.26 at shp1. At shp2, with t-statistics $=0.63$ and 1.12 and P-values $=0.52$ and 0.26 , the dynamic models show that book value is positively related with share price but insignificantly so. From the foregoing, we accept the null hypothesis and conclude that book values are value relevant. 
Table 3. Regression results for model 3

\begin{tabular}{|c|c|c|c|c|c|c|c|c|}
\hline & \multicolumn{8}{|c|}{$P_{j t}=\delta_{0}+\delta_{1} \mathrm{EPS}_{\mathrm{jt}}+\delta_{2} \mathrm{BVPS}_{\mathrm{jt}}+\delta_{3} \mathrm{CFOPS}_{\mathrm{jt}}+\varepsilon_{\mathrm{jt}}$} \\
\hline & \multicolumn{4}{|c|}{ Dependent Variable SHP1 } & \multicolumn{4}{|c|}{ Dependent Variable SHP2 } \\
\hline & $\begin{array}{l}\text { POOLED } \\
\text { OLS }\end{array}$ & $\begin{array}{l}\text { PANEL } \\
\text { OLS }\end{array}$ & REM & FEM & $\begin{array}{l}\text { POOLED } \\
\text { OLS }\end{array}$ & $\begin{array}{l}\text { PANEL } \\
\text { OLS }\end{array}$ & REM & FEM \\
\hline \multirow[t]{2}{*}{ Intercept } & 13.58 & 10.23 & 8.89 & 11.84 & 7.35 & 7.12 & 8.85 & 10.2 \\
\hline & $(-5.16)$ & $(-10.33)$ & -5.87 & -13.03 & -5.67 & -1.56 & -5.47 & -9.92 \\
\hline \multirow[t]{2}{*}{ EPS } & 0.95 & $1.65^{* *}$ & $2.08 * *$ & $1.61 * *$ & $3.05 * *$ & 0.18 & $2.34 * *$ & $1.91 * *$ \\
\hline & -2.37 & $(6.800$ & -8.87 & -7.24 & -2.68 & -1.74 & -9.6 & -7.58 \\
\hline \multirow[t]{2}{*}{ BVPS } & -0.09 & 0.04 & 0.04 & -0.08 & -0.02 & -0.02 & 0.04 & 0.03 \\
\hline & $(-0.61)$ & -0.37 & -0.45 & $(-0.09)$ & $(-0.11)$ & $(-0.47)$ & -0.36 & -0.32 \\
\hline \multirow[t]{2}{*}{ CFOPS } & 1.48 & $2.6^{* *}$ & $3.11 * *$ & $2.03 * *$ & $4.02 * *$ & 0.066 & $3.41 * *$ & $2.92 * *$ \\
\hline & -3 & (11.71 & $(14.68$ & -9.69 & -5.56 & -1.12 & -15.6 & -12.7 \\
\hline$R^{2}$ & 59.2 & 51.3 & 24.1 & 61.3 & 38.1 & 68.6 & 26.6 & 53.9 \\
\hline $\operatorname{Adj} R^{2}$ & 59.1 & 48.6 & 23.9 & 58.4 & 37.9 & 68.5 & 26.3 & 51.4 \\
\hline$F$-stat & 340.1 & $19.15^{* *}$ & $99.45^{* *}$ & $20.4 * *$ & $143.5^{* *}$ & $481.2 * *$ & $112.4^{* *}$ & $21.2 * *$ \\
\hline $\operatorname{Prob}(F-$ stat $)$ & 0 & 0 & 0 & 0 & 0 & 0 & 0 & 0 \\
\hline & \multicolumn{7}{|c|}{$2(1)$} & $2(3)$ \\
\hline \multirow[t]{2}{*}{ (P-values) } & \multicolumn{7}{|c|}{$72.9 * *$} & $70.9 * *$ \\
\hline & $* *$ and $*$ st & cally signi & ant at $1 \%$ a & d $5 \%$ res & ively & & & \\
\hline
\end{tabular}

The table above shows that earnings have positive and significant relationship with share prices. Using the four estimation techniques at shp1 (t-statistics $=2.37,6.8,8.87$ and 7.24) and (P-values $=0.02,0.00,0.00$ and 0.00$)$ at shp2 $(\mathrm{t}$-statistics $=2.68,1.74,9.6$ and 7.58), the results again indicate a rejection of the null hypothesis and non-rejection of the alternative hypothesis that earnings are value relevant for firms in the NSE.

Book values from the estimation results show that under the pool and panel least square, the relationship with share prices is negative but insignificant. Under the dynamic models, there is positive but weak relationship with share price. The pool and panel estimation ( $\mathrm{t}$-statistics $=--0.61$ and 0.37 ) and (P-values $=0.54$ and 0.71 ), using the Random and Fixed effects model (t-statistics $=0.45$ and -0.09$)$ and $(\mathrm{P}$-values $=0.65$ and 0.35$)$ at shp1. At shp2, the pool and panel estimation indicate results with t-statistics $=-0.11$ and -0.47 and $\mathrm{P}$-values $=0.91$ and 0.63 . Using the Random and Fixed effects model (t-statistics $=0.36$ and 0.32 ) and (P-values $=0.72$ and 0.75 ), the null hypothesis is accepted that book value is not value relevant.

Cash flow from operations from the results shows that it is positive, and significantly related to share prices, using the Pool, Panel and the variants of the Panel-REM and FEM. The statistics, such as the t-statistics=3,11.71,14.68 and 9.69 and $\mathrm{P}$-values $=0.002,0.00,0.00$ and 0.00 at shp1. At shp2, the t-statistics $=5.56,1.12,15.6$ and 12.7 and $\mathrm{P}$-values $=0.00$, $0.22,0.00$ and 0.00 respectively. It is therefore concluded that cash flow is value relevant for firms listed on the NSE.

The four estimation techniques, the Pool, Panel, and the REM and FEM, with F-statistics=340.1, 19.15, 99.45 and 20.4) and P-values $=0.00,0.00,0.00$ and 0.00 respectively at shp1, show that the model strongly explains share prices in the NSE and that accounting information is value relevant. The $\mathrm{R}^{2}$ under the Pool, Panel, REM and FEM are 59.2, 51.3 24.1 and 61.3 at shp1 support the foregoing conclusion. 


\begin{tabular}{|c|c|c|c|c|c|c|c|c|}
\hline & Dependent & Variable & & & Dependent & Variable & & \\
\hline & $\begin{array}{l}\text { POOLED } \\
\text { OLS }\end{array}$ & $\begin{array}{l}\text { PANEL } \\
\text { OLS }\end{array}$ & REM & FEM & $\begin{array}{l}\text { POOLED } \\
\text { OLS }\end{array}$ & $\begin{array}{l}\text { PANEL } \\
\text { OLS }\end{array}$ & REM & FEM \\
\hline Intercept & 15.48 & 29.2 & 8.55 & 11.24 & 8.79 & 7.18 & 8.85 & 12.01 \\
\hline & -5.09 & -5.22 & -7.67 & -11.24 & -4.83 & -1.23 & -3.14 & -11.3 \\
\hline$E P S$ & 0.73 & $0.41 * *$ & $1.15^{* *}$ & $0.97 * *$ & 1.57 & 0.15 & $1.46^{*}$ & $1.23 * *$ \\
\hline & -1.54 & -2.55 & -4.76 & -3.83 & -1.23 & -1.52 & -2.29 & -4.62 \\
\hline BVPS & -0.06 & $-0.18 * *$ & $0.22 *$ & 0.13 & 0.15 & -0.02 & 0.23 & 0.13 \\
\hline & $(-0.40)$ & $(-2.74)$ & -2.3 & -1.27 & -1.21 & $(-0.29)$ & -1.03 & -1.25 \\
\hline$D P S$ & 0.011 & $-0.01 *$ & $0.09 * *$ & $0.05 * *$ & $0.09 * *$ & -0.001 & $0.09 * *$ & $0.05^{* *}$ \\
\hline & -0.76 & $(-1.93)$ & -17.6 & -9.66 & -3.19 & $(-0.21)$ & -4.11 & -8.25 \\
\hline$R^{2}$ & 56.5 & 66.1 & 31.1 & 49.1 & 38.8 & 68.9 & 30.5 & 49.4 \\
\hline $\operatorname{Adj} R^{2}$ & 56.3 & 65.9 & 30.9 & 46.3 & 38.5 & 68.8 & 30.3 & 46.7 \\
\hline$F$-stat & $303.2 * *$ & $432.4 * *$ & $140.9^{* *}$ & $17.6^{* *}$ & $147.4^{* *}$ & $488.4 * *$ & $136.7^{* *}$ & $17.8 * *$ \\
\hline $\operatorname{Prob}(F$-stat $)$ & 0 & 0 & 0 & 0 & 0 & 0 & 0 & 0 \\
\hline $\begin{array}{l}\text { Hausman } \\
\text { TESt) }\end{array}$ & & & & $2(1)$ & & & & 2(3) \\
\hline (P-values) & & & & $119.1^{* *}$ & & & & $143.5^{* *}$ \\
\hline & $\begin{array}{l}* * \text { and } * \mathrm{~s} \\
\text { t-statistics }\end{array}$ & istically & $\begin{array}{l}\text { ificant } \\
\text { lesis }\end{array}$ & $\%$ a & spectively & & & \\
\hline
\end{tabular}

From the above table and using the Pool, Panel and the variants REM and FEM estimation techniques, at shp1 the (t-statistics $=1.54,2.55,4.76$ and 3.83) and ( $\mathrm{P}$-values $=0.12,0.01,0.00$ and 0.00$)$ at shp1. At shp2 (t-statistics $=1.23,1.52$, 2.29 and 4.62) and (P-values $=0.22,0.130 .02$ and 0.00$)$ indicate that earnings is positively explains share prices. However, only the dynamic models show significance of relationship consistently, while at shp1 Panel least square indicates the significance of earnings.

For book values at shp1, the results are mixed, while Pool and Panel analysis indicate negative relationship, at shp1, REM and FEM show positive relationship. Panel least square and REM reveal significance in relationship between book values and share price; the other two indicate insignificance. At shp2, Pool, Panel, REM and FEM with t-statistics $=1.21,-0.29,1.03$ and 1.25 and $\mathrm{P}$-values $=0.23,0.78,0.30$, and 0.21 , indicate positive and insignificant relationship between book values and share price.

The relationship between dividends and share price is positive and significant under REM and FEM, (t-statistics=17.6 and 9.66) and (P-values=0.00 and 0.00) at shp1. At shp2 (t-statistics=4.11 and 8.25) with (P-values=0.00 and 0.00). The situation under Pool and Panel are (t-statistics $=0.76$ and -1.13 ) with $\mathrm{P}$-values $=0.45$ and 0.05 at shp1, while at shp2 $\mathrm{t}$-statistics $=3.19$ and -0.21 ) with ( $\mathrm{P}$-values $=0.001$ and 0.83 ). Though these results show a mixed picture, we can largely conclude that taking into account the heterogeneity of the data and addressing the problem of heteroscedasticity dividends are positively and significantly related to share price. Thus we reject the null hypothesis.

The findings from this study are consistent with Babalola (2012) who find earnings more relevant in driving values compared to book values and with Oyerinde (2010); Ghayoumi, Nayemi, Ansari and Raessi(2011) who find that the premium placed on earnings is higher than that placed on book values and Melissa (2013) who observe that dividends and earnings are more value relevant than book values in explaining share prices for listed firms in the Nairobi Stock Exchange. This study however contradicts the findings of Abayadeera (2010) who documents that book values are more important in determining share prices for high-tech firms in Australia relative to earnings.

\section{Conclusion and Policy Recommendations}

This paper has investigated the value relevance of accounting information in Nigeria. The paper provides strong evidence from the price model that accounting information has value relevance in NSE. The period covered by the study was 1994 to 2013. The study was motivated by market-based literature in the U.S, Europe and some emerging 
markets, including developments in the Nigerian Stock Exchange between 2007 and 2010, where the market witnessed dramatic increases in share prices between 2007 and 2008 and a precipitous decline from 2009.

Using a price model derived by Ohlson (1995) and the variants of that model, which included cash flow from operations and dividends, we find that the coefficient estimates of earnings, cash flow and dividends are significant across the four estimation techniques employed in the study. The implication is that these variables are strongly associated with firm value and thus value relevant. The findings of the study have policy implications, not only for regulators but for investors and management of listed firms. The focus of investors should be on earnings, dividends and cash flows and less emphasis should be on book values. For regulators, in order to improve the investment scenario, accounting information communicated to the investing public must be of high quality to avoid sub-optimal investment decision by investors, with consequences for the economy.

Management of listed firms must pay attention to the magnitude of earnings reported in their financial statements. Since earnings have been demonstrated to be associated with asset values, the implication is that firms undertake innovation and investments that generate more earnings. Therefore, companies must pay attention to business expenses; they must find innovative ways of cutting down expenses in order to generate superior earnings.

Further implication of value relevance of dividends and cash flow, may be attributed to the 'buy-hold' attitude of the average Nigerian investor (Osaze, 2007). Therefore, management must ensure regular payment of dividends provided there is a sustainable strong cash flow from operations. Consequently, listed companies in Nigeria must improve the quality of corporate governance, especially as it relates to returns due to investors. Besides, rules, regulations and procedures must be entrenched in the code of corporate governance and the relevant laws to mitigate managerial opportunism, with respect to distributions to shareholders.

\section{References}

Abayedeera, N. (2010). Value relevance of information in hi-tech industries in Australia: Accounting information and intangible assets disclosure. Global Review of Accounting and Finance, 1(1) 77-99.

Abiodun, B.Y. (2012). Significance of accounting information and corporate values of firms in Nigeria. Research Journal in Organisational Psychology \& Educational Studies. 1(2), 105-113. ( www.emergingresource.org)

Ayzer, B.F. \& Cema, I. (2013). Effects of new financial report standards on value relevance. A study of Turkish stock markets. International Journal of Economics and Finance.5(10)10-13. http://ccsenet.org/journal/index.php/ijef/article/viewFile/30676/18065

Barth,M.E., Beaver, W.H. \& Landsman, W.R. (2001). The relevance of value relevance literature for financial accounting standard setting: another view. Journal of Accounting and Economics,31, 77-104. http://dx.doi.org/10.2139/ssrn.246861

Ben Ayed, M. R., \& Abaoub, E. (2006). Value relevance of accounting earnings and the information content of its components: Empirical evidence in Tunisian Stock Exchange, Working Paper, Faculté des Sciences Economiques et de Gestion de Tunis, Université Tunis- El Manar.

Beattie, V. (2000). The future of corporate reporting: A review article. Irish Accounting Review, 7 (1), 1-36. (http://eprints.gla.ac.uk/archive/00000829)

Ball, R. , \& Brown, P. (1968). An empirical examination of accounting income numbers. Journal of Accounting Research, 6(2),159-178. http://dx.doi.org/10.2307/2490232

Ben, N. \& Nachi, W. (2007). Does the Tunisian accounting reform improve the value relevance of financial information? Afro-Asian Journal of Accounting and Finance, 2 (3).( www.inderscience.com)

Beisland,L.A. (2010). Is the value relevance of accounting information consistently underestimated? The Open Business Journal,3(1),1-7.

Brimble, M. \& Hodgson, A. (2007). On the intertemporal value relevance of conventional financial accounting in Australia. Accounting and Finance, 7 (4): 599-662. http://dx.doi.org/10.1111/j.1467-629X.2007.00241.x

Collins, D.W., Maydew, E.L., \& Weiss, I.S. (1997). Changes in the value relevance of earnings and book values over the past forty years, Journal of Accounting and Economics, 24(1), 39-68. http://dx.doi.org/10.1016/S0165-4101(97)00015-3

Core, J.E.,Guay,W.R. , \& Burskirk, A.V. (2003). Market valuation in the new economy: an investigation of what has changed. Journal of Accounting and Economics,34(1) 43-67. http://dx.doi.org/10.1016/S0165-4101(02)00087-3 
Dechow, P.M. (1994). Accounting earnings and cash flow as measures of firm performance: The role of accounting accruals. Journal of Accounting and Economics, 18, 3-42. http://dx.doi.org/10.1016/0165-4101(94)90016-7

Dontoh, A., Radhakrishnan, S. , \& Ronen, J. (2004). The declining value-relevance of accounting information and non-information-based trading: An empirical analysis. Contemporary Accounting Research, 21(4): 795-812. http://dx.doi.org/10.1506/J6P4-2UYP-HFXY-RBT1

Dung, N.V. (2010). Value relevance of financial statement information. A flexible application of modern theories to the Vietnam stock market. Paper presented at the development and policies research center, Vietnam.

Francis, J. Schipper, K. (1999). Have financial statements lost their relevance? Journal of Accounting Research, 37, 319-52. http://dx.doi.org/10.2307/2491412

Ghayoumi, A. F., Nayeri, M. D., Ansari, M., \& Raeesi, T. (2011). Value relevance of accounting information: Evidence from Iranian Emerging Stock Exchange. World Academy of Science, Engineering and Technology, 78. Retrieved from http://waset.org/publications/15331/value-relevance-of-accounting-informationevidence-from

Glezakos, M., Mylonakis, J. \& Kafuoros, C. (2012). The impact of accounting information on stock prices : evidence from Athens stock exchange.

Habib, W.M \& Elhamawy, S.M. (2009). On the value relevance of finance cash flows and accounting accruals: empirical evidence from Egypt. Ains Shams University Journal of Economic studies. 3, 1-22.

Halonen, E., Pavlovia, J. , \& Pearson, R. (2013). Value relevance of accounting information and its impact on stock prices: Evidence from Sweden. Department of /economics Stockholm University abstract : Final version of value relevance of act data evidence. Retrieved $16^{\text {th }}$ December,2014.

Holthausen, R.W., \& Watts, R.L. (2001). The relevance of the value relevance literature for financial accounting standard setting. Journal of Accounting \& Economics. 31(3), 3-75. http://dx.doi.org/10.1016/S0165-4101(01)00029-5

Ibadin,P.O.\& Oladipupo,O.A.(2015).Determinants of intangible assets disclosure in quoted companies in Nigeria.,Asian Journal of Accounting and Governance,6.ajag@ukm.edu.my/norman@ukm.edu.my

Keener, M.H. (2012). The relative value relevance of earnings and book values across industries. Journal of Finance and Accounting. 3(2), 9-19.

Kirkulak and Balsari. (2009). Value relevance of inflation adjusted equity and income. The international journal of Accountng. 44, 363-377. http://dx.doi.org/10.1016/j.intacc.2009.09.007

Lev, B. , \& Zarowin, P. (1999). The boundaries of financial reporting and how to extend them, Journal of Accounting Research, 37(2): 353-385. http://dx.doi.org/10.2307/2491413

Melissa, A.N. (2013). Value relevance of financial statement information: Evidence from listed firms in Kenya. Advances in Management and Applied Economics. 3(1), 115-134

Ng, A.C., Gul, F.A., Mensah, Y.M. (2007). Managerial entrenchment and value relevance of earnings during the preand post-Sarbanes Oxley periods.

Ohlson, J.A. (1995), Earnings, book values and dividends in equity valuation, Contemporary Accounting Research, 11 (2), 661-687. http://dx.doi.org/10.1111/j.1911-3846.1995.tb00461.x

Olga, F. \& Veltri, S. (2012). A critical analysis fo the empirical researches on comprehensive income value relevance. European Journal of scientific research. 76(4) 587-594.

Omokhudu, O.O. , \& Otakefe, J.P. (2005). Accounting information in the petroleum marketing industry. Tropical Focus. 6(3), 173-193.

Ortega, X. (2006). Reinvestigation of value relevance of earnings, book values and cash flow in security prices over time.

Osamwonyi, I.O. , \& Anikamadu, M.O. (2002). The Nigerian Stock Market, efficient market hypothesis and the run test. Nigeria Journal of Business Administration, 4 (2),30-53

Osaze, E.B. (2007). The Nigerian Capital Market in the African and global financial system. Lagos. Bofic Consulting Group.

Oyerinde, D.T. (2009). Value relevance of accounting information in emerging stock market: The case of Nigeria. In 
Repositioning African Business and Development for the $21^{\text {st }}$ Century, Simon Sigue (Ed.).

Perera, R. A. A. S., \& Thrikawala, S. S. (2010). An empirical study of the relevance of accounting information investor's decisions. ICBI, University of Kelaniya, Sri Lanka.

Pourheydari, O., Aflatoon, A. , \& Nikbakhat, Z. (2008). The pricing of dividends and book value in equity valuation: The case of Iran. International Research Journal of Finance and Economics, 13, 1450-2887.

Sami, H. , \& Haiyan, Z. (2004). A comparison of value relevance of accounting information in different segment of the Chinese Stock Market. The International Journal of Accounting, 39, 403-427. http://dx.doi.org/10.1016/j.intacc.2004.08.001

Vijitha, P. ,\& Imalathasan, B. (2014). Value relevance of published financial statements with special emphasis on impact of cash flow reporting. International Research Journal of Finance and Economics, 17(1), $1450-2887$.

Zhao, Y.L. , \& Wang, Z.T. (1999). Empirical research on functional fixation of Chinese Securities Market. Journal of Economic Research, 9,56-63. 